\title{
EFFECT OF PROGESTERONE IN VIVO UPON THE RATE OF CLEAVAGE OF MOUSE EMBRYOS
}

\author{
L. ROBLERO \\ Embryology Laboratory, Institute of Biological Sciences, \\ Catholic University of Chile, Santiago, Chile
}

(Received 19th April 1973)

The effects of ovarian hormones upon the female genital tract have been extensively studied (see Parkes \& Deanesly, 1966a), but very little is known of the effect of ovarian steroids on the early development of the mammalian embryo. It has been shown that oestrogens and progesterone enhance the incorporation of labelled uridine and labelled amino acids in delayed blastocysts of certain mammals (Prasad, Dass \& Mohla, 1968; Weitlauf \& Greenwald, 1968). On the other hand, studies in vitro have shown that progesterone has an inhibitory effect on the early development of mammalian embryos as judged by the arrest of cleavage (Whitten, 1957; Daniel, 1964; Kirkpatrick, 1971). In the presence of macromolecules of the uterine fluid, however, progesterone in vitro has a stimulatory effect as measured by the growth of rabbit blastocysts (El-Banna \& Daniel, 1972).

In the present work, we have studied the effect of progesterone in vivo upon the rate of cleavage during early development of the mouse embryo.

Immature female mice of the Swiss-Rockefeller strain were induced to superovulate with an injection of 5 i.u. PMSG (Gestyl, Organon) followed $44 \mathrm{hr}$ later by an injection of 10 i.u. HCG (Apoidina, Parke Davis). After the HCG injection, the animals were mated with males of proven fertility. The mated females were allocated to three groups: in Group 1, females were left intact and served as controls; in Group 2, females were ovariectomized $34 \mathrm{hr}$ after HCG injection; in Group 3, females were also ovariectomized $34 \mathrm{hr}$ after HCG injection, but beginning at the time of ovariectomy and continuing up to the time of killing, the females of the third group received a daily intraperitoneal injection of $1 \mathrm{mg}$ progesterone. The animals from each group were killed 63, 82 and $87 \mathrm{hr}$ after the estimated time of ovulation. The oviducts and uterine horns were flushed with BMOC-2 (Brinster, 1965) and the recovered embryos were treated with a $0.2 \%$ solution of sodium citrate. The embryos were then fixed with a mixture of glacial acetic acid-ethanol $(1: 3)$ and finally stained with orcein (Tarkowski, 1966). The cell nuclei of each embryo were counted with the aid of a drawing projector.

The results clearly show (Table 1) that embryos of ovariectomized females have significantly fewer cells when compared to embryos from control animals. The embryos recovered from ovariectomized progesterone-treated females had significantly fewer cells when compared to controls but significantly more cells when compared to embryos of ovariectomized females. 
Table 1. Mean number of blastomeres per embryo recovered 63, 82 and $87 \mathrm{hr}$ after ovulation from female mice treated under different conditions

\begin{tabular}{|c|c|c|c|c|}
\hline Group & $\begin{array}{l}\text { No. of } \\
\text { females }\end{array}$ & Treatment & $\begin{array}{l}\text { No. of } \\
\text { embryos }\end{array}$ & $\begin{array}{c}\text { Mean no. of blastomeres } \\
\text { per embryo }\end{array}$ \\
\hline 1 & $\begin{array}{l}8 \\
7 \\
8\end{array}$ & $\begin{array}{l}\text { None (control) }{ }^{\mathrm{a}} \\
\text { Ovariectomized }^{\mathrm{b}} \\
\text { Ovariectomized and }_{\text {progesterone-treated }}{ }^{\mathrm{c}}\end{array}$ & $\begin{array}{l}89 \\
85 \\
91\end{array}$ & $\begin{array}{r}12 \cdot 7 \\
9 \cdot 3 \\
10 \cdot 2\end{array}$ \\
\hline 8 & $\begin{array}{l}8 \\
8 \\
7\end{array}$ & $\begin{array}{l}\text { None (control) } \\
\text { Ovariectomized } \\
\text { Ovariectomized and } \\
\text { progesterone-treated }^{\mathrm{c}}\end{array}$ & $\begin{array}{l}82 \\
87 \\
78\end{array}$ & $\begin{array}{l}39 \cdot 8 \\
15 \cdot 9 \\
25 \cdot 5\end{array}$ \\
\hline 3 & $\begin{array}{l}10 \\
10 \\
10\end{array}$ & $\begin{array}{l}\text { None (control) } \\
\text { Ovariectomized }^{\mathrm{b}} \\
\text { Ovariectomized and }_{\text {progesterone-treated }}\end{array}$ & $\begin{array}{r}119 \\
99 \\
108\end{array}$ & $\begin{array}{l}57 \cdot 4 \\
23 \cdot 0 \\
40 \cdot 6\end{array}$ \\
\hline
\end{tabular}

The $P$ value for all three Groups and all three 'interactions' (a/b, a/c, b/c) in Wilcoxon's Test was $P<0 \cdot 01$, with the exception of $b / c$ for Group 1 where the value was $P<0.02$.

These results suggest that the decrease in progesterone and other ovarian hormones to the low levels occurring following ovariectomy has a detrimental effect upon development of the mammalian embryo. The corollary of the detrimental effect would be that maternal ovarian hormones control early embryogenesis, such as cleavage rate. This hypothesis is supported by the significant increase in the number of cells in embryos recovered from ovariectomized progesterone-treated females compared to the ovariectomized ones. The uterine secretions could be acting as carriers of progesterone to become incorporated into the developing embryo (El-Banna \& Daniel, 1972). This view is supported by the fact that progesterone has a stimulatory effect on the cleavage rate in vitro only when the culture medium contains blood serum (L. Roblero, unpublished results).

The synergistic physiological effects of progesterone and oestrogens have been extensively illustrated (Parkes \& Deanesly, 1966b). These low levels probably have no effect on embryonic development.

I am indebted to Dr C. Barros, Dr L. Izquierdo and Dr C. A. Shivers for valuable discussions and to $\mathrm{Dr} J$. Daniel for reading and commenting on the manuscript.

This work was supported by Grants from the Ford Foundation, from the Catholic University of Chile Research Fund and by a Grant from the Rockefeller Foundation to Dr G. Barros.

\section{REFERENCES}

BRINSTER, R. L. (1965) Studies on the development of mouse embryos in vitro. IV. Interaction of energy sources. F. Reprod. Fert. 10, 227.

DANiel, J. C. (1964) Some effects of steroids on cleavage of rabbit eggs in vitro. Endocrinology, 75, 706. El-Banna, A. A. \& Daniel, J. C. (1972) Stimulation of rabbit blastocysts in vitro by progesterone and uterine proteins in combination. Fert. Steril. 23, 101. 
KiRKPATRICK, J. F. (1971) Differential sensitivity of preimplantation mouse embryos in vitro to oestradiol and progesterone. F. Reprod. Fert. 27, 283.

Parkes, A. S. \& Deanesly, R. (1966a) The ovarian hormones. In: Marshall's Physiology of Reproduction, Vol. III, Chap. 30. Ed. A. S. Parkes. Longmans, Green \& Co., London.

Parkes, A. S. \& Deanesly, R. (1966b) Relation between the gonads and the adrenal glands. In: Marshall's Physiology of Reproduction, Vol. III, Chap. 33. Ed. A. S. Parkes. Longmans, Green \& Co., London.

Prasad, M. R. N., Dass, C. M. S. \& Mohla, S. (1968) Action of oestrogen on the blastocyst and uterus in delayed implantation: an autoradiographic study. F. Reprod. Fert. 16, 97.

TARKowski, A. (1966) An air drying method for chromosome preparations from mouse eggs. Cytogenetics, $5,394$.

Weitlaup, H. M. \& GReenwald, G. S. (1968) Influence of estrogen and progesterone on the incorporation of $\mathrm{S}^{35}$ methionine by blastocyst in ovariectomized mice. F. exp. Zool. 169, 463.

Whitten, W. K. (1957) The effect of progesterone on the development of mouse eggs in vitro. $\mathcal{F}$. Endocr. 16, 80. 